\title{
Monitieteinen \\ käsikirjoitustutkimuksen \\ konferenssi
}

GENESIS - HELSINKI 2017: Creative Processes and Archives in Arts and Humanities 7.- 9. 6. 2017.

Veijo Pulkkinen 
elsingissä kesäkuussa pidetty GENESIS - HELSINKI 2017 oli

H ensimmäinen Pohjoismaissa järjestetty laaja geneettiseen kritiikkiin keskittynyt kansainvälinen konferenssi. Järjestäjinä toimivat Suomalaisen Kirjallisuuden Seura sekä johtava geneettisen kritiikin tutkimuskeskus ITEM - Institut des textes \& manuscrits modernes.

Konferenssin teema oli rajattu väljästi luomisprosessien tutkimukseen arkistoissa ja ihmistieteissä. Yhtäältä tällä tavoiteltiin mahdollisimman monitieteistä konferenssia ja toisaalta pyrittiin kannustamaan osallistumaan konferenssiin myös ilman aiempaa tietoa geneettisestä kritiikistä. Yhtenä konferenssin keskeisenä motiivina olikin geneettisen kritiikin esitteleminen suomalaiselle yleisölle.

Konferenssi tarjosi varsinaisen rautaisannoksen tietoa geneettisestä kritiikistä, sillä kolmen päivän aikana esiintyi peräti kymmenen pääpuhujaa. Kaiken kaikkiaan esitelmiä oli viitisenkymmentä ja osallistujia noin yhdeksänkymmentä neljästätoista eri maasta.

Geneettinen kritiikki on Ranskassa 1970-luvun alussa syntynyt tutkimussuuntaus, jonka kohteena ovat modernit käsikirjoitukset. Aluksi tutkimus keskittyi kirjallisten teosten käsikirjoituksiin, mutta myöhemmin geneettistä kritiikkiä on sovellettu muiden taiteiden lisäksi myös muun muassa filosofisten ja matemaattisten käsikirjoitusten tutkimukseen. Merkittävä geneettisen kritiikin nykysuuntaus on didaktinen kirjoituksen tutkimus, joka oli keskeisessä osassa myös GENESIS - HELSINKI 2017 -konferenssissa. Konferenssin ohessa järjestettiin työpaja, jossa esiteltiin geneettisen kritiikin soveltamista suomalaisille kielten opettajille.

Konferenssin ensimmäisen päivän pääpuhujia yhdisti geneettisen kritiikin ja tekstikritiikin välisten suhteiden pohdiskelu. ITEM:in johtaja Paolo D'Iorio esitteli Friedrich Nietzschen digitaalista editiota (Nietzsche Source) ja sen tarjoamia mahdollisuuksia geneettiseen tutkimukseen. James Joyce -tutkija ja ITEM:in entinen johtaja Daniel Ferrer puolestaan puhui geneettisen kritiikin ja tekstikritiikin nykytilasta ja yhteisistä tulevaisuuden haasteista.

Toisen päivän aloitti Irène Fenoglio (ITEM). Hänen aiheenaan oli kielitieteen ja geneettisen kritiikin suhde. Fenoglio puhui ranskaksi, mutta esitelmän teksti oli saatavilla myös englanniksi käännettynä. Konferenssin ensimmäisen plenaaripaneelin osallistujia olivat Carrie Smith (Cardiff University), joka pohti arkiston käsitettä Ted Hughesin Birthday Letters -kokoelman näkökulmasta sekä Sakari Ylivuori (Jean Sibelius Works), jonka aiheena oli julkaisemattomat nuottikäsikirjoitukset.

Viimeisen päivän aloitti Claire Doquet (Université Paris 3), joka esitteli geneettisen kritiikin soveltamista koulujen kirjoituksen opetukseen. Päivän toinen pääpuhuja oli tekstikriitikko Wim Van Mierlo (Loughborough University), joka pohti arkiston käsitettä geneettisessä kritiikissä. Konferenssin 
toiseen plenaaripaneeliin osallistuivat Samuel Beckettin Play-näytelmää kognitiotutkimuksen ja geneettisen tutkimuksen näkökulmasta tarkastellut Olga Beloborodova (Antwerpenin yliopisto) sekä olemassa olemattomista maalauksista puhunut Juha-Heikki Tihinen (Pro Artibus -säätiö). Konferenssin viimeiset pääpuhujat olivat Ineke Huysman (Huygens ING, Alankomaat), joka esitteli varhaismoderneja kirjeitä, sekä Dirk Van Hulle (Centre for Manuscript Genetics, Belgia), joka pohdiskeli mahdollisuutta soveltaa kognitiotutkimusta geneettiseen kritiikkiin.

Rinnakkaissessioissa tarkasteltiin syntyprosesseja ja arkistoaineistoja kirjallisuuden lisäksi muun muassa filosofian, musiikin, vaatesuunnittelun, psykologian, valokuvauksen, kääntämisen, kuvituksen ja suullisen runouden näkökulmista.

Loppusanojen yhteydessä julkaistiin tieto, että konferenssi saa jatkoa kahden vuoden päästä pidettävässä GENESIS - CRACOW 2019 -konferenssissa.

GENESIS - HELSINKI 2017 -konferenssin ohjelma, abstraktit sekä linkkejä videoituihin esitelmiin löytyvät osoitteesta: http://www.finlit.fi/fi/tutkimus/ kriittiset-editiot-edith/genesis-helsinki-2017\#.Wfw0zYZx2Rs 